\title{
Role of Women in the Development of India - A Case Study
}

\author{
* K. Tejaswani, ** M. Lalitha Sridevi \\ * First Author: K. Tejaswani, Department of English, GITAM University, Hyderabad. \\ ** Second Author: M. Lalitha Sridevi, Department of English, GITAM University, Hyderabad.
}

\begin{abstract}
The contribution of women in the development of a nation has oft been neglected. Especially in developing countries, seldom do we see women entrepreneurs who make an impact on the country's economy and who contribute to the building of the nation. The present study is carried out with an intention to bring out the significant contribution of women entrepreneurs in India. The aim of the study is to emphasize the extensive outcomes of collective efforts of women force in India.

The role of Chanda Kochchar in banking sector is considered as a case study for the present article. Born on November 17, 1961, she graduated from Jai Hind College, Mumbai and obtained masters in management studies from Jamnalal Bajaj Institute of Management Studies. She was awarded Wockhardt Gold Medal for Excellence in Management Studies and J. N. Bose Gold Medal for securing the highest marks in Cost Accountancy. She was rightly awarded the Padma Bhushan award by the Government of India for her impressive services to the banking sector.

The aim of this article is to focus on the diverse business strategies in handling crises in the banking sector. The article tries to develop the case study in order to identify the skills that made ChandaKochchar a leader.

Keywords: banking sector, Chanda Kochchar, development of nation
\end{abstract}

\section{Introduction:}

Started on a modest scale as a subsidiary of an Indian financial institution, ICICI, in 1954, ICICI bank was originally known as Industrial Credit and Investment Corporation of India. The bank, initially a development financial institution, used to offer project finance to a diversified financial services group. In 1987, ICICI Ltd along with Unit Trust of India (UTI) set up Credit Rating Information Services of India Limited (CRISIL), India's first professional credit rating agency. In 1990s, the bank diversified into a wide variety of products and services. The bank has many firsts to its credit along with being the first bank from Asian Continent apart from Japan listed on New York Stock Exchange (NYSE). In 1991, ICICI Personal Financial Services Limited and ICICI Capital Services Limited merged with ICICI Bank. ICICI also played a pivotal role in creating National Commodities and Derivatives Exchange Limited (NCDEX), Financial Innovation Network and Operations Ltd. (FINO), Entrepreneurship Development Institute of India (EDII), North Eastern Development Finance Corporation (NEDFI), Asset Reconstruction Company India Ltd. (ARCIL), and Credit Information Bureau of India Ltd. (CIBIL) along with other nationalized banks and financial organizations. ICICI bank has won many awards such as 'The Best Bank' awarded by The Asset Triple A (2012), Best Remittance Business Award at The Asian Banker's International Excellence in Retail Financial Services 2013 Awards ceremony to name a few.

ICICI Bank also took an active part in providing elementary education for underprivileged children through the 'Read to Lead' programme which reached out to more than one million elementary school going children.

The year 2008 was a challenging year for ICICI bank which invested in Lehman Brothers, USA. When Lehman Brothers collapsed the toll immediately fell on ICICI as well. Along with the challenge came an opportunity for ICICI to present its strength to the world. Chanda Kochchar was one such individual who played an integral role in the success of ICICI bank.

\section{Introduction to Chanda Kochchar:}

India had its share of business women from times immemorial. From running a home to running a business, time and again women have proved themselves as astute and keen in business. ChandaKochchar's widowed mother was her role model who transited from being a homemaker into a determined career woman to provide for her family. Chanda Kochchar acknowledges her mother's traits of grit and determination in the face of odds as her initial lessons in leadership skills [6].

Along with Kiran Mazumdar, Chairman and MD - Biocon Limited, Kalpana Vinita Bali, MD - Britannia, Renuka Ramnath - , RenuSudKarnad - MD - HDFC, Vanitha Narayanan, MD - IBM India, Pallavi Shroff, Senior Partner, Amarchand \& Mangaldas \& Suresh A. Shroff \& Co., Shubha Lakshmi Panse - MD Allahabad 
Bank, Vinita Singhania - MD JK Cements to name a few Indian business women, Chanda Kochchar also plays an influential part in developing the country.

\section{Chanda Kochchar's banking career:}

For a woman who joined ICICI as a management trainee in 1984, it is a gigantic leap to become the CEO and MD of ICICI on $1^{\text {st }}$ May, 2009 within a short span of 15 years. Her ladder of success also shows her versatility in all phases of banking relationships. Her versatility is evidenced by the fact that she excelled in all the fields that ICICI offered her. In fact, challenges nurtured her growth and ICICI's growth besides spiralling India's economic growth. She gracefully adorned highly responsible positions in ICICI and brought accolades to the domains she served. In 2000, Kochchar who was working with the Corporate banking sector was asked to take up retail sector on K. V. Kamath's recommendation. Though she was hesitant to move out of corporate sector which she helped to evolve in a big way and take up a relatively new field, she took only one day to decide. And in the retail field also she proved herself. Kochchar kept the doors of ICICI open 12 hours a day whereas the other banks were open for only 4 to 7 hours. A pioneer of electronic banking, she was influential in opening ICICI bank ATM machines.

According to Kochchar, an individual's career growth will be unsurpassed when work becomes relaxation as well as passion. Taking responsibility and delivering competently comes effortless to Kochchar. The ICICI board members have expressed that Kocchar's “deep experience across the bank's businesses would be invaluable in providing stability while at the same time charting the bank's future in the emerging global environment." [2]

\section{Opportunity as a challenge:}

Several online journals and magazine reports on the strategies employed by Chanda Kochchar were referred to affirm her approach in dealing with crises in business. Chanda Kochchar, a woman who is credited to see an opportunity in a challenge proved her mettle at the time of 2008 disaster beyond doubt. Along with Mr. K. V. Kamath, her mentor and predecessor and Finance Minister of India, P. Chidambaram tried her best to dispel the doubts of panicking customers that ICICI bank might collapse along with Lehman Brothers. She realized that mere assurances are not going to restore confidence among the customers who were demanding for their deposits. Hence, she made a crucial decision of giving their money back in spite of the adversity the bank was facing. Her ideology is based on the quote of Mahatma Gandhi:

"A customer is the most important visitor on our premises. He is not dependent on us. We are dependent on him. He is not an interruption in our work. He is the purpose of it. He is not an outsider in our business. He is part of it. We are not doing him a favor by serving him. He is doing us a favor by giving us an opportunity to do so."

Her unwavering strength, decision making and risk taking skills, flexibility and resilience were proved beyond doubt in dealing with the 2008 crisis. She left no stone unturned to retain customers. She went ahead and talked with customers advising them not to panic as their money was in safe hands. When her assurances could not diminish the panic, the story goes that she rented several armoured trucks to ship cash to various branches of ICICI all over India. The banks were kept 24 hours open to calm the terrified customers. It was a tough time for the security guards as they stocked and guarded the fully loaded ATMs as panicked customers were queuing to withdraw their money. When the ATMs exhausted their stock, it is said that she gave orders to commute the customers to nearby branches and ATMs where they could withdraw money [6]. This act of hers boosted the credibility of ICICI bank to an enormous extent. Perseverance at difficult times, determination to succeed, transparent communication with the customers, ability to delegate, instilling confidence and commitment to promises are some qualities that make her stand apart from the other business individuals. For prospective employees, her business skills and strategies provide substantial inputs to transform them into leaders.

\section{Discussion:}

Kochchar does not believe in expanding the existing workforce, but uses it efficiently in the expansion of various branches across the country. She employs the traditional mode by returning to her retail roots instead of concentrating on sales agents- a usual method used in India. She displays immense maturity in executing a plan of action like the measures she has taken in lowering the funding costs substantially. The bank is now concentrating on mortgages and car loans in order to develop safer modes in lending portfolio. She has also reduced the cost of expenditure by $10 \%$ by settling leases on various branches and also rented apartments for travelling executives which comes to a negligible amount when compared to the price of a hotel room. 
Leadership, in the present day, encompasses a different paradigm from that of yesteryears. The new generation leaders need to focus on skills like customer- centred vision, self- confidence and business ethics in order to carve a niche in the business world [8].

A customer- centred vision acts a guiding force to create a positive impact on the customers. Chanda Kochchar serves as a lighthouse for students in guiding them to create a vision slightly beyond reach so that they use their potential talent to generate enthusiasm among customers.

Self- confidence is another important trait that comes from positive attitude even in adverse situations. Students must have the right attitude and this helps them in taking up challenges positively. Kochchar's selfconfidence is an exemplary characteristic for students to project themselves as confident leaders. Michael Porter, a distinguished professor at Harvard Business School, quotes, "[t]he best CEOs I know are teachers and at the core what they teach is strategy."

Chanda Kochchar adds a spiritual dimension to management by creating a culture in which values play an important role. Her mantra that "I take all the stress on myself so everyone else can work without stress," expresses a blend of ethical values and strong sense of commitment towards her work.

According to eminent scientist and former President of India, "educationists should build the capacities of the spirit of inquiry, creativity, entrepreneurial and moral leadership among students and become their role model." Unfortunately, words like 'pressure,' 'stress,' 'crisis' etc. have a negative connotation in the minds of many people. The true potential of a person comes out only when he encounters 'pressure,' 'stress,' 'crisis' etc. These situations should be seen as opportunities to prove one's mettle. Thinking out of the box doesn't mean going into a different box, albeit a bigger one. It should help one encompass all thoughts, inside and outside the box. Only the mediocre assume and shift from one box to another whereas the creative and innovative reinvent on the base of the old ideas. Predicting which solution is correct for a problem one encounters and if the same solution might work if the problem recurs is impossible. The recurrence of the problem itself is a proof that the solution is not error-free. An open mind and objective thinking is always advisable when seeking solutions which affect millions of people.

\section{Chanda Kochchar's future goals:}

Chanda Kochchar is channelizing her efforts in making ICICI one of the top 20 banks in the world. The U.S. and British banks are considered to be the rivals of ICICI with cut-throat competition in the field of banking as they have huge resources and are ambitious to make it big in banking sector. Nevertheless, Kochchar has the ability to make this dream come true through her grit and determination and lead ICICI to the summit.

\section{Conclusion:}

In the present generation, enthusiasm and taking initiative are the two core skills that are lacking among the employable youth. For those of us who are teaching professional undergraduates it is a task to inculcate employable skills to the students. Most of the students are under the assumption that employable skills are to be developed while working. Au contraire, in today's cutthroat competition the organizations neither have time nor inclination to invest in training basic employable skills to the fresh recruits. Employable skills which are very different from expertise in core subjects can only be acquired with a lot of practice and training for which the prospective employers cannot allot time. These skills should be ingrained in the students at the level of graduation itself.

Leaders are not only born they can be mentored as well. This can be achieved by analyzing the business strategies of successful people and imbibing those skills. The business strategies of Chanda Kochchar are plain, simple and are those that give satisfaction and gain the trust of the customers. Kochchar herself makes it clear that she is not here to run a race; she is here to carefully execute a plan drafted well before schedule [2]. At the same time she also is aware of the risks and pitfalls and moreover is ready with modifications to reach her goal. The path is easy for the person who has a vision and plan for the unpredictable.

\section{References:}

[1]. $\quad$ http://finance.fortune.cnn.com/tag/icici-bank/, $16^{\text {th }}$ Oct., 2013.

[2]. http://www.resonance.ac.in/reso/studentzone/anunnad/anunaad-16.pdf, $10^{\text {th }}$ October, 2013.

[3]. http://en.wikipedia.org/wiki/ICICI_Bank, $16^{\text {th }}$ Oct., 2013.

[4]. http://en.wikipedia.org/wiki/ICICI Bank, $16^{\text {th }}$ Oct., 2013.

[5]. http://www.thomaswhite.com/global-perspectives/chanda-kochhar-ceo-and-md-icici-bank/, $16^{\text {th }}$ Oct., 2013.

[6]. http://inventivelinks.com/story-of-chanda-kochhar/, $10^{\text {th }}$ October, 2013.

[7]. http://finance.fortune.cnn.com/2011/10/04/chanda-kochhar-icici-bank/, $10^{\text {th }}$ October, 2013.

[8]. V.V. Ramani (ed.) Leadership in Today’s Business World. Hyderabad: ICFAI UP, 2004. 